\title{
Commentary: Van Beelen [2016] SASCFC 71
}

\author{
David R. A. Caruso* and Brigid Symes \\ Litigation Law Unit, The University of Adelaide, Adelaide, SA, Australia \\ Keywords: second appeal, scientific advance, fresh evidence, compelling evidence, substantial
}

\section{A commentary on}

Van Beelen [2016] SASCFC 71

\section{INTRODUCTION}

On 15 July 1971, Deborah Leach was found dead on the beach. Dr. Manock, the State forensic pathologist, used stomach content analysis to determine the time of Leach's death. Manock concluded that death was between 4:00 p.m. and 4:30 p.m. Only Mr. Van Beelen had been witnessed on the beach during this time. Van Beelen was convicted of Leach's murder in $1973 .{ }^{1}$ His conviction was upheld on appeal. ${ }^{2}$

In 2013, South Australian appellate law was amended to permit second and subsequent appeals if there was "fresh" and "compelling" evidence. ${ }^{3}$ This reversed the common law position that allowed for only a single, perfected appeal. ${ }^{4}$ Van Beelen's case was subsequently appealed in $2016 .{ }^{5}$ The defense argued that scientific development concerning stomach content analysis constituted fresh and compelling evidence. The Appeal Court rejected that argument by majority.

\section{OPEN ACCESS}

Edited by:

Alex Biedermann,

University of Lausanne, Switzerland

Reviewed by:

Paul Roberts,

University of Nottingham,

United Kingdom

${ }^{*}$ Correspondence:

David R. A. Caruso

david.caruso@adelaide.edu.au

Specialty section:

This article was submitted to

ELSI in Science and Genetics,

a section of the journal

Frontiers in Sociology

Received: 20 October 2017 Accepted: 28 November 2017 Published: 20 December 2017

Citation:

Caruso DRA and Symes B (2017)

Commentary: Van Beelen [2016] SASCFC 71.

Front. Sociol. 2:20.

doi: $10.3389 /$ fsoc.2017.00020

\section{STOMACH CONTENT ANALYSIS AT THE 1973 TRIAL}

Manock relied on Leach's schoolmates for the content and timing of her last meal: a pasty, a glass of milk, and a slice of pie between 12:15 p.m. and 12:30 p.m. Manock found that Leach's stomach was three-quarters empty at death. He concluded that death could not have occurred before 3:30 p.m. or after 4:30 p.m. Dr. Pocock testified, for the defense, that it would "indeed be a rash, irresponsible man, who would dare pronounce the exact time of death in the witness-box; or for that matter, be ready to estimate the time even to within an hour on either side of the actual time." ${ }^{6}$

\section{SCIENTIFIC DEVELOPMENTS IN THE 2016 APPEAL}

In 2016, Professor Horowitz testified that stomach content analysis was now considered to be an unreliable way to accurately measure the time of death. This was due to the enormous variations in digestion between individuals. Horowitz testified that gastric emptying rates cannot (now) be estimated to within an hour. ${ }^{7}$ He said that even in the 1970s, it was completely unreliable science to provide an estimate of time of death once gastric emptying had commenced. ${ }^{8}$

\footnotetext{
${ }^{1}$ See R v Van Beelen (1973) 4 SASR 353.

${ }^{2} \mathrm{R}$ v Van Beelen (No 3) (1973) 7 SASR 125.

${ }^{3}$ Statutes Amendment (Appeals) Act 2013 (SA) (No 9 of 2013) section 7.

${ }^{4} \mathrm{R} v$ Edwards (No 2) (1931) SASR 376; Grierson v The King (1938) 60 CLR 431.

${ }^{5} \mathrm{R} v$ Van Beelen (2016) 125 SASR 253.

${ }^{6} \mathrm{R} v$ Van Beelen (2016) SASCFC 71 (129) Vanstone and Kelly JJ.

${ }^{7} \mathrm{R} v$ Van Beelen (2016) SASCFC 71 (50) Kourakis CJ.

${ }^{8} \mathrm{R} v$ Van Beelen (2016) SASCFC 71 (31) Kourakis CJ.
} 


\section{COURT'S REASONING}

Kourakis CJ, Vanstone and Kelly JJ comprised the secondary appeal court. They agreed that the evidence of Horowitz was "fresh" within the meaning of the legislation. The point of difference was that the Majority (Vanstone and Kelly JJ) did not consider the evidence "compelling"; the Chief Justice did.

"Fresh" and "compelling" are defined. Evidence relating to an offense is "fresh" if: (i) it was not adduced at the trial of the offense; and (ii) it could not, even with the exercise of reasonable diligence, have been adduced at the trial. That same evidence is "compelling" if: (i) it is reliable; and (ii) it is substantial; and (iii) it is highly probative in the context of the issues in dispute at the trial of the offense.

The Majority held that the evidence was not "compelling" because Horowitz's evidence was not "substantial." ${ }^{\prime 0}$ This was due to the doubt already placed on Manock's evidence by Pocock in the original trial. ${ }^{11}$ The Majority did not consider the prosecution case turned on the expert evidence regarding time of death. The Majority gave particular attention to the civilian evidence at the 1973 trial that set the parameters for Leach's death as occurring between 4:00 p.m. and 4:40 p.m., or at the latest 4:50 p.m. The fresh evidence was only capable of showing that time of death could have been a mere 10 or $20 \mathrm{~min}$ later. The Majority considered that, as a result, the evidence of Horowitz was not substantial and, therefore, not compelling. ${ }^{12}$

\section{OPINION}

Common law courts vested with secondary appeal powers are obliged to review scientific advance within the confines of its possible meaning and interpretation in an historic trial. Appellate rights must be constrained by the trial issues to realize the utility in litigation ending. That is a narrow lens for what may be wideranging gains in scientific knowledge. The purpose of secondary appellate legislation should be to permit scientific advancement to expose errors of fact-finding at trial. The conclusion of the Majority requires the relevant evidence to be substantial in light of the trial as a whole. The provisions of section 353A, however, do not require the evidence to be considered in light of the trial holistically. The fresh evidence itself must be substantial. Kourakis CJ identified why the evidence was substantial: its reputable source and basis in current science.

Compelling evidence under the legislative regime is "highly probative in the context of the issues" at the trial. Scientific

\footnotetext{
${ }^{9}$ Criminal Law Consolidation Act 1935 (SA), section 353A (6).

${ }^{10} \mathrm{R}$ v Van Beelen (2016) SASCFC 71 (159) Vanstone and Kelly JJ.

${ }^{11} \mathrm{R}$ v Van Beelen (2016) SASCFC 71 (162) Vanstone and Kelly JJ.

${ }^{12} \mathrm{R}$ v Van Beelen (2016) SASCFC 71 (164) Vanstone and Kelly JJ.
}

advance is almost ubiquitously probative with respect to evolution of human knowledge, but the courts are concerned with a more restricted notion of probity. The "probative value" of expert evidence to the law concerns the effect that evidence would have on the rational assessment of issues before the court. In the case of secondary appeals, the probative value lies in the extent to which the expert evidence would compel re-assessment of the original trial issues. This symbiotic relationship between the probative value of expert evidence and the disputed issues reveals why the reasoning of Kourakis $\mathrm{CJ}$ is to be preferred.

Probative value is to be assessed in the context of the issues, not the evidence, in dispute. The Majority rejected Horowitz's evidence as compelling because there was other lay evidence, which diminished the import of stomach contents emptying regarding time of death. The legislation does not invite the appellate court to examine the issues in dispute having regard to the evidence in the trial court. The requirement that evidence justifying a secondary appeal must be "fresh" guards against evidence being re-litigated or agitated on secondary appeal. If evidence adduced on secondary appeal relates to an issue in the trial below which the context of the trial reveals to be an important issue in the dispute at trial, then, the definition of "compelling" indicates that the subject evidence should be regarded as highly probative in the context of the issues in dispute. The time of death was a key element in the prosecution case and, without its certainty, a possibility arose that someone other than Van Beelen committed the offense..$^{13}$ The Chief Justice found the relationship of Horowitz's evidence to the time of death was highly probative as the timing of death was an issue central to the context of the dispute at the 1973 trial.

In a trial where time of death is in issue and the context of the trial places emphasis on the timing of death, fresh evidence concerning errors in that timing should satisfy the criterion of "compelling." Secondary appellate legislation should be, unless a contrary parliamentary intention can be clearly shown, read with a view to assess whether the fresh evidence is compelling given the issues in the court below, not the evidence in the court below.

Van Beelen appealed the split decision to the High Court of Australia and the matter was heard in June $2017^{14}$; final judgment is pending.

\section{AUTHOR CONTRIBUTIONS}

This commentary was jointly written with a $80 / 20$ division of work in reviewing the subject case.

\footnotetext{
${ }^{13} \mathrm{R}$ v Van Beelen (2016) SASCFC 71 (72) Kourakis CJ.

${ }^{14} \mathrm{R} v$ Van Beelen (2017) HCATrans 19.
}

Conflict of Interest Statement: The authors declare that the research was conducted in the absence of any commercial or financial relationships that could be construed as a potential conflict of interest.

Copyright (C) 2017 Caruso and Symes. This is an open-access article distributed under the terms of the Creative Commons Attribution License (CC BY).
The use, distribution or reproduction in other forums is permitted, provided the original author(s) or licensor are credited and that the original publication in this journal is cited, in accordance with accepted academic practice. No use, distribution or reproduction is permitted which does not comply with these terms. 